\title{
Coping with landslide risk through preventive resettlement. Designing optimal strategies through choice experiments for the Mount Elgon region, Uganda
}

Pieter Vlaeminck ${ }^{1}$, Miet Maertens ${ }^{1}$, Moses isabirye ${ }^{2}$, Filip Vanderhoydonks ${ }^{1}$, Jean Poesen ${ }^{1}$, Jozef Deckers $^{1}$ and Liesbet Vranken ${ }^{1}$

This document is a postprint version.

The published version can be found at http://www.sciencedirect.com/science/article/pii/S0264837715003865

(doi:10.1016/j.landusepol.2015.11.023)

\begin{abstract}
Landslides significantly affect rural income-generating activities in the East African highlands. In addition, the livelihoods of the poorest are most likely to be adversely affected. Traditionally, landslide risk is reduced by means of effective planning and management. In many regions, these measures are insufficient to offer a long-term solution because of high population density and land shortage. We use a choice experiment to investigate whether preventive resettlement could be a feasible disaster risk reduction strategy for the population at risk in agricultural areas in Bududa district, East Uganda. Our study provides the first analysis of resettlement-related preferences of people that are affected by environmental degradation. Our results enable us to assess community support for resettlement strategies ex-ante and provide valuable policy advice for future resettlement plans in a very cost-effective manner.
\end{abstract}

Key Words: Stated preference, rural development, disaster risk reduction, displacement, community support, environmental degradation

JEL classification: C83, Q15, Q20, Q53, Q54

\footnotetext{
${ }^{1}$ Division of Bioeconomics, Department of Earth and Environmental Sciences, KU Leuven, Celestijnenlaan 200 E-box 2411, 3001 Leuven (Heverlee), Belgium

${ }^{2}$ Faculty of Natural Resources and Environment, Namasagali Campus, Busitema University, Kamuli, Uganda
} 


\title{
Coping with landslide risk through preventive resettlement. Designing optimal strategies through choice experiments for the Mount Elgon region, Uganda
}

\author{
Pieter Vlaeminck, Miet Maertens, Moses isabirye, Filip Vanderhoydonk, Jean Poesen, Jozef \\ Deckers and Liesbet Vranken
}

\section{Introduction}

The increase in frequency and intensity of natural disasters is worsened by both climate change and an increasing population living in high risk areas (Artur and Hilhorst, 2014; Rukundo et al., 2014; Black et al., 2011; WB/UN, 2010; Guterres, 2008). Since poor people tend to live on marginal lands that are most sensitive to natural hazards, they are most likely to be affected by small changes in climate variability (UNDP, 2004; FAO, 2000). One type of hazard with severe projected impact and widespread consequences are landslides. Landslides have a large social, economic and geomorphological impact as they significantly reduce agricultural productivity, increase soil degradation, damage property and infrastructure, and cause casualties (Mugagga et al, 2012; Holcombe and Anderson, 2010; Claessens et al., 2007; Knapen et al., 2006; Shiferaw, 2002). The East African Mountains are known to be a region inherently susceptible to landslides because of high annual rainfall, steep and unstable slopes, and ongoing deforestation (Broothaerts et al., 2012; Van Den Eeckhaut et al., 2009; Knapen et al., 2006; Glade and Crozier, 2004). Increasing population pressure is an important underlying factor, leading to slope disturbance, inconsiderate irrigation and deforestation. The poorest people are most likely to be adversely affected by natural hazards such as landslides since low agricultural income reduces the capacity to cope with risks (Vu et al., 2014; Dercon, 2006).

Effective planning and management, such as (geo-) technical measures, reforestation and development of early-warning systems, can substantially reduce the impact of landslides (Holcombe and Anderson, 2010; Dai et al., 2002). In many regions, high population density and land shortage make these measures insufficient to offer a long-term solution (Claessens et al., 2007; Knapen et al., 2006). Preventive resettlement from high-risk areas has been 
considered a possible disaster risk reduction strategy in response to increased natural hazards (Artur and Hilhorst, 2014; Claudianos, 2014; Correa et al, 2011). This requires financial and social capital and might only be feasible with governmental and non-governmental support, especially if high-risk areas have a high incidence of poverty (Lübken, 2012).

In this paper, we investigate ex-ante whether a preventive resettlement policy could be a feasible long-term risk reduction strategy to cope with landslide risk in the Mount Elgon region in East Uganda. We focus on the population at risk and the necessary conditions to design community supported resettlement strategies in this area. We consider resettlement as a key adaptation for managing natural and other risks, and thus not just as a problematic outcome of global environmental change (Black et al. 2011).

Our focus on the Mount Elgon region, and more specifically on the Bududa district in this region, is particularly relevant. The region as a whole and the Bududa district in particular, are repeatedly hit by smaller and larger landslides, leading to severe calamity. The region stands as an example for the steep, upland areas of the wet tropics that face a high population density and pressure. People encroach steep slopes and clear forest to get access to land for building their houses and generating an income through agriculture. These anthropogenic factors greatly contribute to the occurrence of landslides (Gorokhovich et al. 2013; Knapen et al., 2006) which makes a focus on resettlement as a landslide risk reduction strategy pertinent.

We use a discrete choice experiment to examine whether resettlement is a feasible coping strategy to mitigate landslide risks on Mount Elgon, and if so under which conditions and compensatory schemes. This is a survey-based stated preference elicitation method that allows modelling preferences for hypothetical preventive resettlement strategies thereby revealing which strategies have a higher likelihood to be community supported. We also investigate whether the willingness to resettle depends on the landslide risk that the population currently faces. 
Previous literature, especially the literature on development-induced forced displacement and resettlement (DFDR), identified two major problems with past resettlement policies. First, compensation alone does not work to restore people's livelihoods as it ignores the social and cultural consequences of displacement (Kabra and Mahalwal, 2014; Bui et al., 2013; Maldonado, 2012; Wilmsen et al., 2011; Cernea and Mathur, 2007; Webber and McDonald, 2004). Second, the majority of negative consequences following involuntary resettlement could have been prevented if projects had given room for greater community participation and consultation throughout the resettlement project design and implementation (Claudianos, 2014; Diduck et al., 2013; Brand, 2001). This paper incorporates these two perspectives. Through this first consultation round, we hope to limit the possible negative impacts of a non-targeted forced resettlement in the future by giving a platform for the peoples' voices to be heard and get insights into the preferences of the local population to shape this future strategy.

Our study provides the first ex-ante analysis of preferences for resettlement from environmentally fragile areas to create room for bottom-up policy planning. Our results enable us to give valuable policy advice for different resettlement policies which are not yet implemented in a very cost-effective manner. Through a well-designed preventive resettlement scheme, government can limit the elements at risk, thereby reducing the expected economic loss and loss of life due to landslides in the future.

\section{Background}

\subsection{Description of area and landslides}

The $274 \mathrm{~km}^{2}$ research area of Bududa district is located in eastern Uganda on the southwestern foot slopes of the extinct Mt. Elgon volcano, 20 kilometers east of Mbale, a large trade hub (Figure 1). Bududa district was created in 2006 when it was separated from Manafwa 
district. The altitude ranges from 1300 to $2850 \mathrm{~m}$ a.s.l. and the district has a wet tropical climate.

The average annual rainfall depth is $1800 \mathrm{~mm}$ with two separated rainy seasons, one from March to June and the second from August to November. The average annual temperature is $23^{\circ} \mathrm{C}$ (BDPU, 2012) and is more or less constant the whole year round.

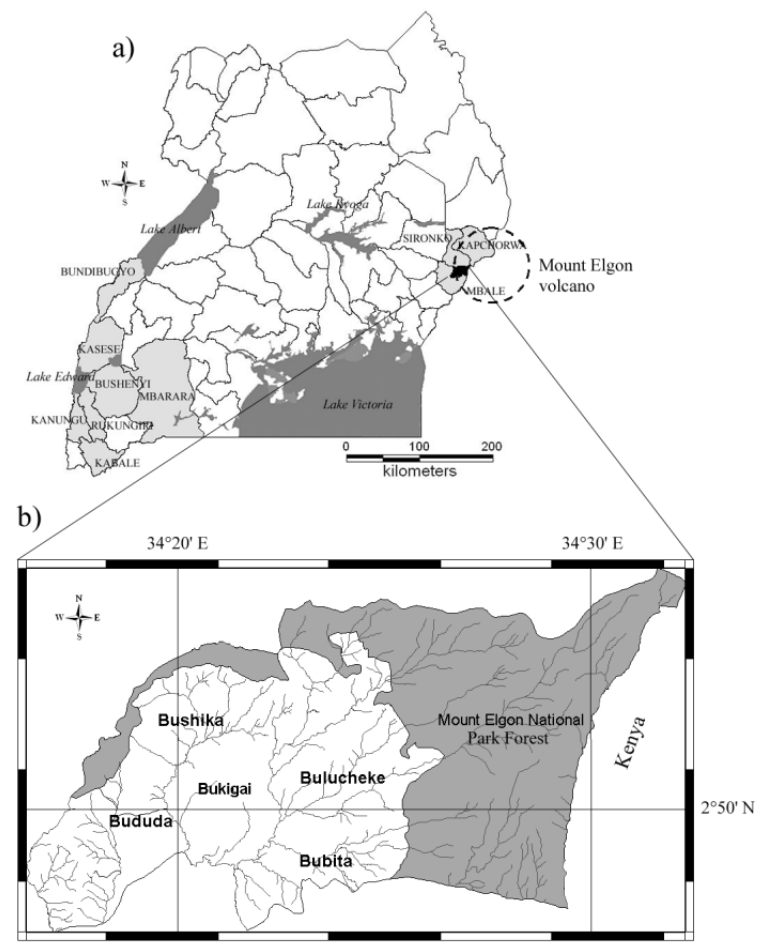

Figure 1. Location of the study area, Bududa district, in Uganda (after Knapen et al., 2005)

Topographic, climatic and soil conditions together with human activities make of Bududa district a landslide-prone $\operatorname{area}^{2}$ (Knapen et al., 2006). Most landslides occur on east and north orientated slopes (dominant rainfall direction) with slope angles exceeding $14^{\circ}$ (see Figure 2 for an impression of a landslide in Bududa district).

\footnotetext{
${ }^{2}$ Topographic conditions are mainly related to slope steepness, climatic conditions to the high annual rainfall depth and soil conditions to the high clay content. The main impacts of human presence relate to cultivation, deforestation, and excavations for housing, agricultural activities, irrigation, and the establishment of foot paths and roads.
} 


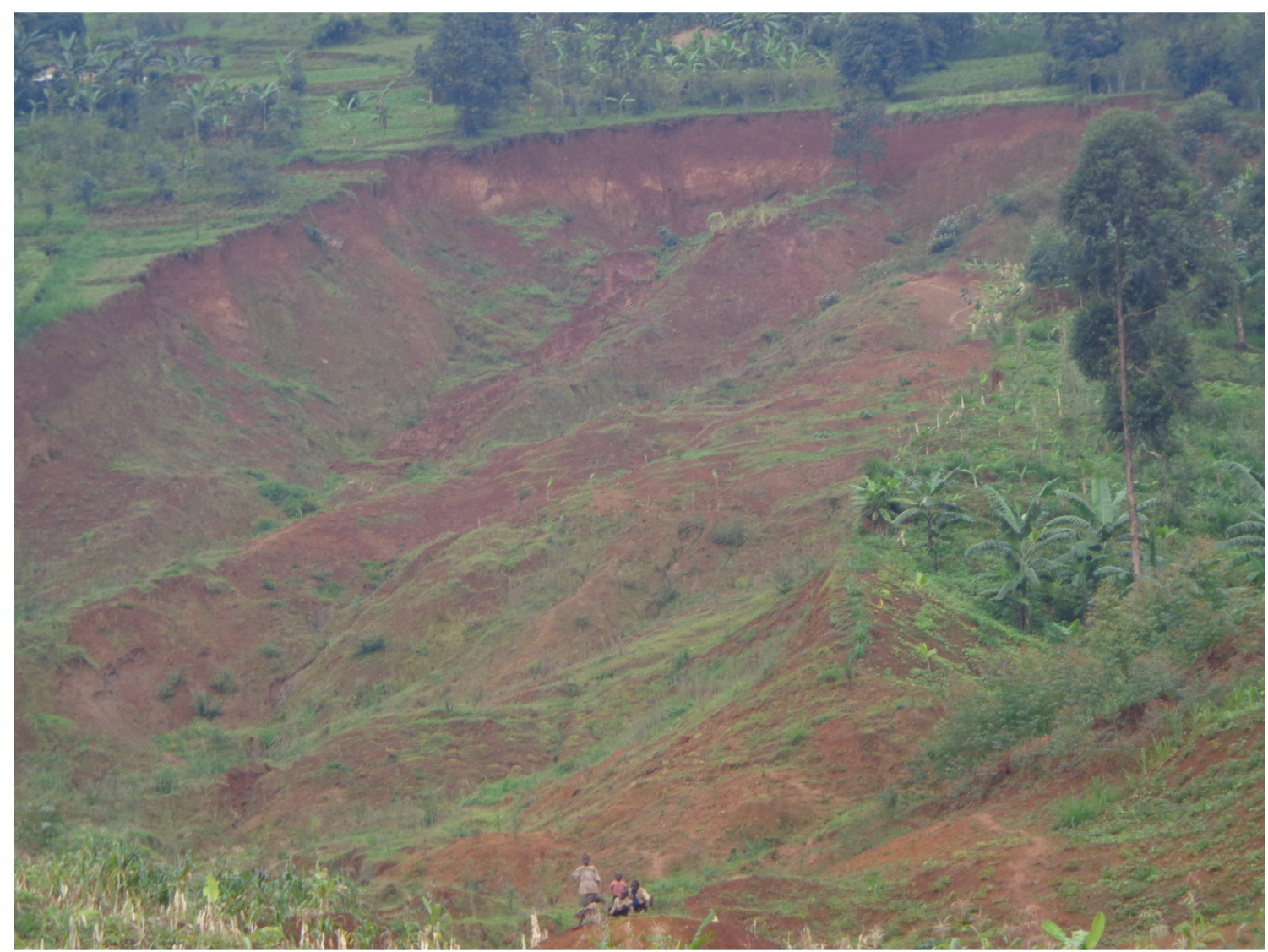

Figure 2. Impression of a landslide in Bududa district (Courtesy of the authors)

Based on soil type, the district can be divided into three zones (Kitutu et al., 2009). The Central Bukigai zone is characterized by a carbonatite rock dome which has no landslides due to high cohesion of cementing minerals such as calcium carbonate (Kitutu et al., 2009). It has a low population density compared to the other two zones because soils are less fertile (Claessens et al., 2007; Knapen et al., 2005). The second zone is the Western Bududa-Bushika zone where different soil types can be identified i.e. Cambisols, Nitisols, Acrisols and Lixisols. Landslides are relatively rare but contribute significantly to the landslide problem due to their large dimensions and the high population density of the area (Knapen et al., 2006). In the populated Eastern Bukalesi zone, soils have higher clay contents which lead to lower sheer strengths during the rainy season. Landslides occur rather frequently and are shallower than in the Western zone because the parent material is nearer to the surface.

\subsection{Agriculture and population pressure}


Bududa has an estimated population of 182,867 people (BDPU, 2012), living in 16 subcounties, including one town council. Agriculture is the most important economic activity for over $86 \%$ of the households living in the 16 different subcounties (BDPU, 2012). The current farming system is mixed crop-livestock farming. The main crops grown are banana, coffee, beans, cocoyam, cassava, sugarcane, onions and sweet potato. Coffee, especially Arabica, is the most popular cash crop and almost all farmers are producing for the market. An average population density of 952 persons $/ \mathrm{km}^{2}$, rising up to more than 1300 persons $/ \mathrm{km} 2$ in the

densely populated parishes in the west, makes available land per household very small. A population growth rate of 5.6\% since 1991 predicts even smaller land areas per household and more cultivation of unstable, steeper slopes (sometimes $>80 \%$ ). Agricultural pressure and weak governance of land use will cause increased deforestation and excavations leading to a further reduction of slope stability in the near future (Mugagga et al, 2012). Besides, due to climate change, the seasonal weather patterns are expected to become more extreme. On the one hand, this will strongly affect the way farmers can use their land and hence farmers' income and food security (Oxfam, 2008). On the other hand, it will increase the likelihood of a landslide occurrence. The interplay between high population density, land shortage, and climatic changes results in larger exposure to landslides. Therefore the economic risk by slope failure is projected to increase (Knapen et al., 2006).

\subsection{Socio-economic impact of landslides}

Landslides have a disastrous effect on the livelihoods of the farmers in Bududa district, resulting in income loss and loss of productive land (Rukundo et al., 2014; Gorokhovich et al., 2013; Jenkins, et al. 2013; Knapen et al., 2006). Farmers lose cash crops as most of the coffee and banana farming takes place on the steep concave slopes, ranging between $36^{\circ}$ and $58^{\circ}$ which are prone to slides (Mugagga et al., 2012; Kitutu et al., 2011). The debris of landslides imposes 
the government with direct economic costs related to the reconstruction of bridges, roads, dams and the obligatory funding of the disaster relief aid. The indirect costs such as decreased water quality and reduced land fertility can easily outweigh these direct costs (Knapen et al., 2006).

Generally, the catastrophic landslides follow after extreme rainfall events that can be attributed to global weather patterns associated with the El Niño Southern Oscillation. Knapen et al. (2006) describe the type of chain reaction that landslides can have on the livelihoods of Bududa people. In 1997, landslides killed at least 48 people, erased the crops and dwellings of 885 families, made 5600 people homeless, reduced the area of arable land causing land-scarcity and property conflicts, polluted water supplies with a consecutive epidemic and hit Manjiya County with a food-shortage. More recently, in 2010, a major landslide triggered by heavy rains struck the village of Nametsi, killing over 300 people and affecting a population of about 10,000 people which needed to be evacuated to a UN-funded temporary camp in Bulucheke. This landslide eventually triggered the first permanent landslide-induced resettlement to Kiryandongo in Western Uganda (Rukundo et al., 2014; Gorokhovich et al. 2013; Jenkins et al., 2013).

\section{Preventive resettlement as risk reduction strategy}

Disaster risk reduction strategies are being used to limit vulnerability and to strengthen institutions and communities for effective risk management. Landslide risk can be expressed in the following generic hazard-risk equation (Crozier and Glade, 2006):

\section{Risk $=$ hazard $x$ vulnerability $x$ elements at risk}

This equation identifies the principal factors contributing to risk, where risk itself is defined as the expected loss in a unit of time. First, hazard consists of the probability that a damaging landslide of a given magnitude occurs. Second, vulnerability is expressed as the damage expected from the specified landslide magnitude. Last, the elements at risk represent 
the value of all elements at risk such as population, buildings, economic activities, public services utilities and infrastructure in the area.

Landslide risk reduction strategies emphasize preventive measures such as planning and awareness, land use planning and physical intervention in the territory to lessen both people's as well as infrastructure's exposure to natural hazards. Societies are becoming reluctant to invest in (geo-) technical measures that can reduce natural risks because of the high costs associated with these engineering and technical works (Guzzetti et al., 1999). These high associated costs make (geo-) technical measures such as slope stabilization less suited for large, environmentally degraded hillside areas in a developing context where governments are financially constrained.

Only recently, countries have opted for preventive resettlement as a disaster risk reduction strategy, especially if the risk to which a population is exposed cannot be mitigated by any other measure in a long-term sustainable manner. Preventive resettlement reduces the elements at risk, thereby decreasing one of the independent factors of the hazard-risk equation zero, and may even result in the nullification of the risk condition (Correa et al., 2011). Preventive resettlement to reduce exposure is suitable when (1) the local topography makes mitigation impossible, (2) there is a clearly defined area at risk of landslide, and (3) the most at risk communities can be identified to be resettled (Claudianos, 2014). Moreover, if resettlement is to be successful, it should form part of a comprehensive disaster risk reduction strategy controlling human settlement in unsuitable areas and human activities that exacerbate natural hazards (Correa et al., 2011). 


\section{Methodology and data}

\subsection{Resettlement Assessment through Discrete Choice Experiments}

To assess individual's preferences for preventive resettlement strategies we rely on a discrete choice experiment (DCE) introduced by Louviere and Hensher (1982). This is a surveybased stated preference elicitation method that allows modelling preferences for hypothetical resettlement strategies and thereby revealing which strategies have a higher likelihood to be community supported. In a DCE respondents are presented with several choice sets that include alternative varieties of a good or service - in this case a resettlement strategy - differentiated by their attributes and attribute levels, and asked to select their most preferred alternative. A baseline alternative, corresponding to the status quo or 'stay on-site' situation is included in each choice set in order to interpret the results compared to the current situation. At least one attribute of the alternative is systematically varied across respondents so that preference parameters of an indirect utility function can be inferred (Carson and Louviere, 2011).

DCE rely on random utility theory which states that a respondent's utility function is comprised of a deterministic, observable component $(V)$ and a random, unobservable component $(\varepsilon)$ (Christie et al., 2004):

$$
U_{i j t}=V_{i j t}+\varepsilon_{i j t}=\beta X_{i j t}+\sigma_{i} X_{i j t}+\varepsilon_{i j t},
$$

Where $U_{\mathrm{ijt}}$ represents the utility a respondent $\mathrm{i}$ derives from choosing alternative $\mathrm{j}$ on choice situation $\mathrm{t}, \mathrm{X}_{\mathrm{ijt}}$ is a vector of $\mathrm{k}$ observed attributes for the resettlement strategies ( $\mathrm{k}$ being the number of attributes), $\beta$ is the vector of preference parameters associated with the attributes, $\sigma_{\mathrm{i}}$ is a vector of $\mathrm{k}$ standard deviation parameters, and $\varepsilon_{\mathrm{ijt}}$ is a stochastic error term, independently and identically distributed (iid) according to a Gumbel distribution (Louviere, Hensher \& Swait, 2000). One choice set comprises several resettlement scenarios. Choosing one alternative over 
the others implies that the utility of the chosen alternative exceeds the utility derived from the other alternatives (Ben-Akiva \& Lerman, 1985). Respondents' preferences are generally estimated through maximum likelihood in logit models (Ben-Akiva \& Lerman, 1985). Parameter estimates are derived from the log-likelihood function associated with the logit model.

\subsection{Choice Experiment Design}

To assess individual preferences for resettlement plans we conducted a survey that included socio-demographic questions as well as a choice experiment. The construction of a choice experiment includes three important stages: the identification of the attributes describing the alternatives within each choice set, the identification of the attribute levels and the experimental design. To identify the attributes, semi-structured interviews were conducted among six subcounty chiefs, an officer of the Office of the Prime Minister and the National Environmental Management Authority. In addition, four focus-group discussions (FGD), each consisting of five women and five men, were organized. In Nametsi and Bukalasi subcounty one FGD was organized while in Bibiita subcounty two FGD took place. Finally a workshop was organized in Mbale with the aim of testing the feasibility of the attributes and the attribute levels which were identified as important during the semi-structured interviews and FGD. All subcounty chiefs as well as representatives of the Red Cross, the Ugandan Wildlife Authority, the District of the Local Governments and the UNDP were invited to participate in the workshop. A screening of the resettlement literature together with the information gathered during the interviews, the FGD and the workshop allowed identifying six resettlement attributes and the relevant attribute levels (Table 1). 24 Choice cards divided over two blocks were designed using the NGene software (D-efficient design) and tested in a pilot survey which 
allowed to further fine-tune the survey and choice experiment. An example of a choice card is shown in Figure 3.

Table 1. Attributes and their corresponding attribute levels

\begin{tabular}{|c|c|c|}
\hline Attributes & Levels & Explanation/Background \\
\hline \multirow[t]{4}{*}{ Location } & Same subcounty & Within subcounty, but different location \\
\hline & Within Bududa district & Same district, but different subcounty \\
\hline & Within Bugisu ${ }^{3}$ sub-region & Same sub-region, but different district \\
\hline & Outside Bugisu sub-region & $\begin{array}{l}\text { Outside their cultural region, anywhere in } \\
\text { Uganda }\end{array}$ \\
\hline \multirow[t]{3}{*}{ Housing compensation } & Single house & Permanent single house \\
\hline & Baracks & Multiple attached single houses \\
\hline & Multi-story & Multi-story building \\
\hline \multirow[t]{3}{*}{ Health services } & Health Center 4 & Highest level of health services (hospital) \\
\hline & Health Center 3 & Intermediate level of health services \\
\hline & Health Center 2 & Lowest level of health services \\
\hline \multirow[t]{3}{*}{ Education services } & $\begin{array}{l}\text { Primary } \\
\text { Vocational }\end{array}$ & Highest level of education services \\
\hline & Primary + Secundary & Intermediate level of education services \\
\hline & Primary & Lowest level of education services \\
\hline \multirow[t]{3}{*}{ Monetary compensation } & $250,000 \mathrm{UGX}$ for 12 months & Average income of a Ugandan is \\
\hline & $250,000 \mathrm{UGX}$ for 6 months & UGX 336,900 per month \\
\hline & 250,000UGX for 0 months & \\
\hline \multirow[t]{3}{*}{ Land compensation } & Same amount of land & $\begin{array}{l}\text { Same amount as you possessed before (WB- } \\
\text { policy) }\end{array}$ \\
\hline & Half the amount of land & Half the amount, you possessed before \\
\hline & No amount of land & No amount of land will be compensated \\
\hline
\end{tabular}

Note: 2538.34 Uganda Shillings (UGX) per US\$ (Mid-rate 2013/2014); Attribute levels in italics resemble the base level of each attribute.

\footnotetext{
${ }^{3}$ The Bugisu sub-region is located in the Eastern region and consists of the following five districts: Bududa District, Bulambuli District, Manafwa District, Sironko District, and Mbale District. The sub-region is home mainly to the Gisu People.
} 


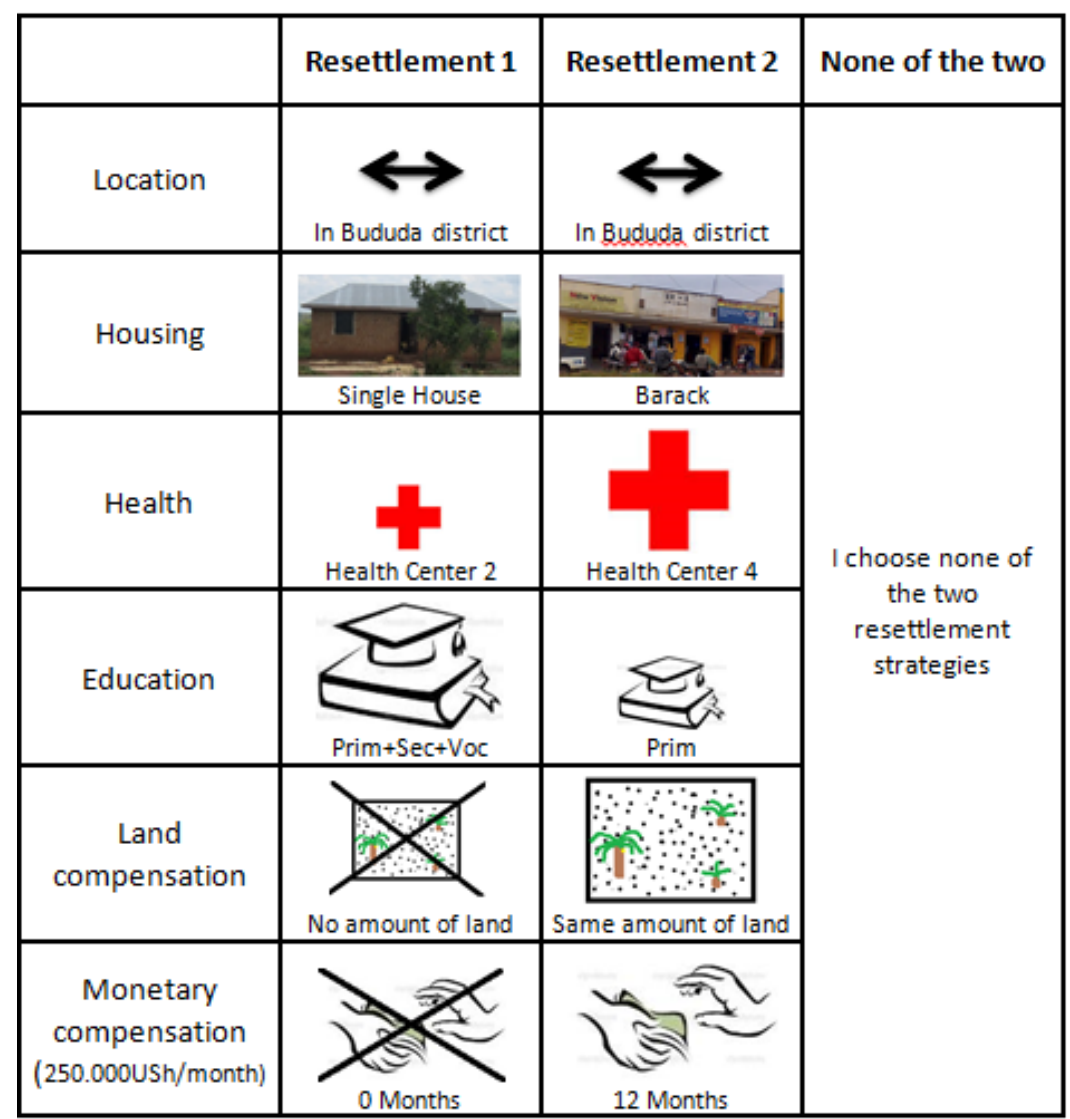

Figure 3. Example of a choice card with two resettlement scenarios and a status quo.

\subsection{Choice Experiment Procedure, Sampling and Split Sample Approach}

During the period August - October 2013, we interviewed 307 household heads in the entire Bududa district ${ }^{4}$. Since detailed and validated landslide susceptibility maps - covering both shallow and deep-seated landslides - were not available for Bududa district, it was unfortunately impossible to stratify our sample based on landslide risk on forehand. Therefore, we relied on the last population census predictions for each subcounty for the sampling procedure. The total population of Bududa district was estimated at 182,867 in 2012 and the number of respondents interviewed in each subcounty was set proportional to the subcounty's

\footnotetext{
${ }^{4}$ The duration of one interview took on average 30 minutes. To make sure that the person understood the choice experiment, we first gave him/her a test card. It was emphasized that the research was conducted independently and was not issued by a governmental body. Finally we included a 'cheap talk' script to reduce the propensity of respondents to answer in a way to please the interviewer (Cummings et al, 1995). Interested readers can contact the authors to get a detailed outline of the experimental procedure.
} 
population size. We aimed to collect data for 300 respondents. The projections based on the census didn't give exact numbers for each subcounty and these numbers were round up which resulted in a total sample of 307 respondents. From each subcounty, we randomly selected a number of villages and within each village we interviewed maximum 10 households. The number of villages selected per subcounty was set so that the required number of respondents per subcounty could be reached.

According to Kitutu (2009), Bududa district can be divided in 3 zones: West BududaBushika zone, Central Bukigai zone and East Bukalasi zone. In the Central Bukigai zone, no signs of landslides could be found. In the West Bududa-Bushika zone a few landslides happened in the past, while a lot of landslides took place in the East Bukalasi zone (Knapen, 2006). The West Bududa-Bushika zone consists of 6 subcounties, the Central Bukigai zone of 3 and the East Bukalasi consists of 7 subcounties. Our sampling procedure ensured that respondents were selected from each of the zones and that our sample was proportional to the population size of the subcounties and thus of the zones.

In our analysis, we explicitly account for the fact that landslide risk can still significantly differ within each zone defined by Kitutu et al. (2009). Therefore, we have split our overall sample of respondents being exposed to differing levels of landslide risk into a low risk and a high risk sample. This split is based on two key variables related to landslide risk. The first variable is the self-reported steepness of households' agricultural land as this is a key precondition factor for a landslide to occur ${ }^{5}$. The second variable is whether a landslide already occurred in a village. This variable measures the factual (higher probability that another landslide happens) and perceived likelihood that a landslide will happen in their surroundings. These two variables constitute an ideal interplay between objective facts and own perception

\footnotetext{
${ }^{5}$ In case participants had multiple scattered plots, we asked them to record the steepness of their agricultural land where their house was located. So steepness records both the steepness of the location of their house and their surrounding plots.
} 
which both have been shown to influence choice behaviour in other fields (e.g. Baker et al., 2009). We allocate people living on steep slopes or people living in a village where a landslide already happened to the high risk population group. People that live on flat or gentle slopes and never experienced a landslide in their village are allocated to the low risk population group. This approach allows us to assess how resettlement preferences differ with the varying level of landslide risk and consequently to give more valuable and detailed policy advice.

\section{Choice experimental results}

\subsection{Descriptive statistics}

Table 2. Summary statistics for full sample and low risk/high risk samples

\begin{tabular}{|c|c|c|c|}
\hline Characteristics & Full Sample & $\begin{array}{l}\text { Low risk } \\
\text { population }\end{array}$ & $\begin{array}{l}\text { High risk } \\
\text { population }\end{array}$ \\
\hline \multicolumn{4}{|l|}{ Socio demographics } \\
\hline $\mathrm{N}^{\circ}$ of Respondents & 307 & 104 & 203 \\
\hline Male household heads (\%) & 93 & 94 & 93 \\
\hline Age of the household head (years) & 42 & 43 & $40 * * *$ \\
\hline Average household size (\# persons) & 7.9 & 7.4 & $8.1 * * *$ \\
\hline Literacy rate $(\%)$ & 54 & 63.5 & $51 * * *$ \\
\hline Households with farming as main occupation (\%) & 83 & 83 & 83 \\
\hline Farmers growing coffee $(\%)$ & 94 & 93 & 95 \\
\hline Monthly income (UGX) & 387,452 & 424,182 & $368,634 * * *$ \\
\hline Land cultivad (acres) & 2.39 & 2.27 & $2.45^{* * *}$ \\
\hline Average livestock holdings (Livestock Units) & 2.05 & 2.15 & $1.95 * * *$ \\
\hline Households living in semi-permanent house $(\%)$ & 81 & 72.5 & $84 * * *$ \\
\hline \multicolumn{4}{|l|}{ Resettlement attitude } \\
\hline Households willing to resettle $(\%)$ & 73 & 61 & $89 * * *$ \\
\hline $\begin{array}{l}\text { Households willing to give up land to reduce } \\
\text { landslide risk }(\%)\end{array}$ & 84 & 83 & 88 \\
\hline
\end{tabular}

In Table 2 we summarize the main sample characteristics. Descriptive statistics are given for the full sample as for the high risk population $(n=203)$ and low risk population groups $(n=104)$. The socio-economic profile of the high risk population differs significantly from the low risk population. First, people living in the riskier areas are significantly younger compared 
to people living in the low risk areas ${ }^{6}$. Second, there is an inverse relationship between household income and the riskiness of the household's land. People who live in the low risk areas have a significantly higher income than people living on riskier land. Further, households in the high risk areas are larger in size, own less livestock units, live more frequently in a semipermanent house (hut) and have a higher incidence of an illiterate household head. Farming is the main income-generating activity and almost all farmers cultivate coffee. Concerning resettlement attitude, as a first indication, $73 \%$ of respondents expressed a willingness to resettle which was defined as willing to leave current land and get new safer land elsewhere. This number increases significantly to $89 \%$ for people living in risky areas. Finally, $84 \%$ of respondents in our sample were willing to give up part of their agricultural land to mitigate landslide risk.

\subsection{General random parameters model}

The results of estimating the random parameter logit model for the full sample are reported in Table 3 . The significantly positive coefficient of the alternative specific constant Resettlement (coded as 1 for resettlement and 0 for staying in their current house) implies that there is a general willingness to resettle compared to keep on living in landslide prone areas. People prefer to receive a monetary compensation, and the more the better. There is a strong willingness to be resettled within the Bugisu region, and especially within Bududa district compared to being resettled outside their culturally similar Bugisu area. This could indicate that people do not want to be resettled outside their ancestral and cultural lands due to the strong land attachment. Moreover, if they are resettling not too far away from the land they are currently owning and cultivating, the household could still keep on generating a modest income from this land.

\footnotetext{
${ }^{6}$ Differences in continuous variables were tested with two sample t-tests with unequal variances while Pearson chi-square tests were run for categorical variables.
} 
Table 3. Random parameter logit model results for both the general model as the risk population groups.

\begin{tabular}{|c|c|c|c|c|c|c|}
\hline \multirow[b]{2}{*}{ Variables } & \multicolumn{2}{|c|}{ General Model } & \multicolumn{2}{|c|}{ High risk population } & \multicolumn{2}{|c|}{ Low risk population } \\
\hline & Coeff. & Se. & Coeff. & Se. & Coeff. & Se. \\
\hline Resettlement (ASC) & $0.990 * * *$ & $(0.159)$ & $1.940 * * *$ & $(0.200)$ & -0.0185 & $(0.317)$ \\
\hline Monetary comp & $0.0988 * * *$ & $(0.000)$ & $0.0427 *$ & $(0.0234)$ & $0.243 * * *$ & $(0.0458)$ \\
\hline Bugisu region & $1.476 * * *$ & $(0.141)$ & $1.165 * * *$ & $(0.129)$ & $1.889 * * *$ & $(0.307)$ \\
\hline Bududa district & $1.873 * * *$ & $(0.160)$ & $1.932 * * *$ & $(0.168)$ & $2.255^{* * *}$ & $(0.351)$ \\
\hline Subcounty & $1.732 * * *$ & $(0.161)$ & $1.502 * * *$ & $(0.163)$ & $1.761 * * *$ & $(0.312)$ \\
\hline Barracks & $-0.226 * * *$ & $(0.085)$ & $-0.144 *$ & $(0.0840)$ & $-0.407 * *$ & $(0.168)$ \\
\hline House & $-0.186^{* *}$ & $(0.089)$ & -0.127 & $(0.0881)$ & $-0.349 *$ & $(0.204)$ \\
\hline HealthCenter3 & 0.000978 & $(0.089)$ & 0.0232 & $(0.0882)$ & -0.0733 & $(0.178)$ \\
\hline HealthCenter4 & 0.0307 & $(0.083)$ & 0.0552 & $(0.0854)$ & -0.136 & $(0.191)$ \\
\hline Prim + Sec & -0.0936 & $(0.082)$ & -0.0710 & $(0.0833)$ & 0.0585 & $(0.163)$ \\
\hline Prim + Sec + Voc & 0.121 & $(0.086)$ & $0.165^{*}$ & $(0.0886)$ & 0.0276 & $(0.199)$ \\
\hline Half land & $0.217 * *$ & $(0.106)$ & 0.109 & $(0.0976)$ & $0.533 * *$ & $(0.250)$ \\
\hline Same land & $0.516 * * *$ & $(0.109)$ & $0.366 * * *$ & $(0.103)$ & $0.858 * * *$ & $(0.257)$ \\
\hline SDbugisu & $1.645 * * *$ & $(0.154)$ & $0.991 * * *$ & $(0.154)$ & $2.403 * * *$ & $(0.299)$ \\
\hline SDbududa & $2.389 * * *$ & $(0.198)$ & $1.484 * * *$ & $(0.175)$ & $2.594 * * *$ & $(0.310)$ \\
\hline SDsubcounty & $2.020 * * *$ & $(0.165)$ & $1.586 * * *$ & $(0.180)$ & $2.631 * * *$ & $(0.316)$ \\
\hline SDbarracks & $-0.594 * * *$ & $(0.127)$ & -0.231 & $(0.201)$ & $0.677 * *$ & $(0.298)$ \\
\hline SDhouse & $0.666 * * *$ & $(0.117)$ & $0.309^{*}$ & $(0.179)$ & $-1.272 * * *$ & $(0.232)$ \\
\hline SDHC3 & $0.625 * * *$ & $(0.131)$ & $0.374 * *$ & $(0.154)$ & $0.580 * * *$ & $(0.201)$ \\
\hline SDHC4 & $0.394 * * *$ & $(0.142)$ & 0.0818 & $(0.200)$ & $-0.866 * * *$ & $(0.181)$ \\
\hline SDPS & $-0.527 * * *$ & $(0.121)$ & $-0.356^{* *}$ & $(0.156)$ & $-0.551 * *$ & $(0.280)$ \\
\hline SDPST & $0.398 * *$ & $(0.166)$ & $0.343 * * *$ & $(0.121)$ & $-0.756 * * *$ & $(0.204)$ \\
\hline SDhalfland & $0.913 * * *$ & $(0.122)$ & $-0.306^{*}$ & $(0.164)$ & $1.372 * * *$ & $(0.262)$ \\
\hline SDsameland & $0.939 * * *$ & $(0.115)$ & $0.449 * * *$ & $(0.124)$ & $1.662 * * *$ & $(0.263)$ \\
\hline Log Likelihood & -2649.9 & & -16 & & & \\
\hline McFadden $\mathrm{R}^{2}$ & 0.359 & & & & & \\
\hline Observations & 11,052 & & 7,3 & & 3,7 & \\
\hline
\end{tabular}

Note: $* * *$ significant at $1 \%$ level. SD: standard deviations of random parameters. Both ASC and price attribute are kept non-random. Models have been estimated with 500 Halton draws and random parameters are assumed to follow a normal distribution. All categorical variables were dummy coded.

For the housing attribute we find that both barracks and a single house are less preferred than being resettled into a multi-story building. This result might seem surprising at first. However a couple of explanations could be hypothesized. First, respondents might link the construction of flats to a general development of the area (increase in services) since electricity, running water, etcetera are needed to be constructed when people live in multi-story buildings. Second, due to the population pressure in Bududa district, people may realize that there is no space to resettle into a single house within the area. Last, from government consultations we 
inferred that government plans are being developed to create semi-urban centers in flat areas to absorb the population that lives on the steep slopes. It could well be that these government plans already circulated among the affected population. Both health center and schooling attributes are insignificant for the respondents although these attributes were put forward as important in the focus group discussions. It seems that when asking people to make a resettlement choice and trade-off different attributes against each other, health and schooling services become of secondary importance compared to other attributes such as the new location of their house and compensation. Besides, this dominance can also be explained by a gender effect as $93 \%$ of our respondents are male. Finally, regarding the land compensation, they prefer to be compensated with the same area of land as they were holding before the resettlement which confers with the World Bank land for land swap policy.

\subsection{Split sample results: high risk versus low risk population}

Although the full model provides general insights, it is important to understand whether the willingness to resettle is dependent on the probability of a landslide occurring and whether preferences differ under these different landslide risk situations. The significant standard deviations of the parameter distributions show that preference heterogeneity is present for all normally distributed random parameters. Therefore, to exploit this heterogeneity, we run a split sample model based on two key variables linked to landslide risk and subdivide our sample into high risk population and low risk population ${ }^{7}$.

Results of the split sample random parameter model (Table 3) show that the respondents' choice behaviour is dependent on the likelihood of a landslide occurring. This means that landslide risk significantly affects people's willingness to resettle. People living in the riskiest areas have

\footnotetext{
${ }^{7}$ We ran split sample models since latent class models did not give interpretative results due to the variance matrix being non-symmetric or highly singular.
} 
a strong willingness to resettle independent of compensation. The low risk population group has no willingness to resettle (insignificant ASC) unless they receive a high compensation in terms of money and land. When we control for income, age and type of dwelling in our regression analysis ${ }^{8}$, it becomes clear that people want to keep their current level of livelihood. Older people, people with a higher income or living in a permanent house are significantly less willing to resettle and ask a significantly higher compensation.

\subsection{Attribute importance}

Usually, researchers calculate willingness-to-pay/willingness-to-accept (WTP/WTA) measures in order to compare and interpret the results in standard welfare economic terms ${ }^{9}$. We chose not to do so for several reasons. First, our choice experiment model of resettlement captures a mixture of WTP/WTA which depends on the respondent's perceived landslide risk as well as the risk associated with resettling and this can confound welfare estimates. On the one hand, people should be willing to pay for a future scenario in which they are unexposed to landslide risk. On the other hand, resettlements embody negative impacts on people's lives physically, economically, socially and culturally (Maldonado, 2012). People opting for resettlement should be compensated for these potential losses. Second, the status quo or baseline scenario is different for every respondent making it difficult to estimate accurate welfare estimates as we did not use a pivot design. Third, we do not want to put a price-tag on human lives (Maldonado, 2012). We thus feel it is unethical to report biased willingness-toaccept estimates if these in turn would be used in a future resettlement scenario to compensate the Bududa people.

\footnotetext{
${ }^{8}$ Authors can be contacted to share these results with interested readers.

${ }^{9}$ One cannot compare parameters directly between logit models because the numerical values of the parameter weights are confounded with a scale parameter (Swait and Louviere, 1993).
} 
Instead, we calculate attribute importance so that preferences of the high risk and low risk population can be interpreted and compared for the different resettlement attributes in nonmonetary terms (Lizin et al., 2012) ${ }^{10}$. Attribute importance signals the relative contribution of each attribute to the overall utility for each respondent. Table 4 shows the attribute importance for the general model, and the high and low risk groups.

Respondents attach the highest importance to the resettlement location attribute within the three models. However, both the general willingness to resettle and the importance of compensation clearly differ between the two subsamples. Those who experienced a landslide in their village or live on steep land are more willing to resettle while monetary and land compensations contribute less to their overall utility compared to low risk groups. Attribute importance scores confirm that landslide risk significantly affects the relative contribution of a resettlement to the overall utility of each respondent. For the high risk group, resettlement gets a factor loading of $60 \%$ compared to $2 \%$ for the low risk population groups.

Table 4. Relative attribute importance for general model and risk population groups.

\begin{tabular}{rccc}
\hline & $\begin{array}{c}\text { General } \\
\text { model } \\
(\mathrm{n}=307)\end{array}$ & $\begin{array}{c}\text { High risk } \\
\text { population } \\
(n=203)\end{array}$ & $\begin{array}{c}\text { Low risk } \\
\text { population } \\
(n=104)\end{array}$ \\
\hline Resettlement & $44 \%$ & $59 \%$ & $2 \%$ \\
Monetary compensation & $13 \%$ & $1 \%$ & $20 \%$ \\
New location & $18 \%$ & $23 \%$ & $40 \%$ \\
Housing type & $2 \%$ & $1 \%$ & $5 \%$ \\
Level of health services & $1 \%$ & $1 \%$ & $5 \%$ \\
Level of education services & $9 \%$ & $7 \%$ & $3 \%$ \\
Amount of land compensation & $13 \%$ & $8 \%$ & $26 \%$ \\
\hline & $100 \%$ & $100 \%$ & $100 \%$ \\
\hline
\end{tabular}

On top of that, the compensation asked differs significantly with landslide risk. Less monetary compensation is asked by people living on steeper slopes or by people that have experienced a landslide in their village in the past ${ }^{11}$. The proposed amounts of monetary

\footnotetext{
${ }^{10}$ Attribute importance can be calculated as follows: (1) calculate the utility range per attribute, (2) sum up the utility ranges and (3) divide the attribute utility range by the sum of the utility ranges.

${ }^{11}$ It is indeed expected that people living in lower risk zones will have a lower willingness to resettle or need to be compensated more. The fact that our model results confirm this hypothesis should not be seen as trivial but as
} 
compensation (1\%) do not influence their choice for a future resettlement scenario. The minor importance of monetary compensation can be an indication that the high risk population assesses the extent of future income losses due to landslides as being very high. Their choice is driven by the location to which they will be resettled (23\%), the amount of land they will get after resettlement (8\%) and the opportunity to have improved access to education services $(7 \%)$. This shows that it is not a solution to send them to a destination outside Bugisu, even when you compensate them with money. Other factors such as the cultural region and the possibility of improved social services contribute more to their overall welfare.

\section{Discussion: accounting for challenges to implement preventive resettlement}

Our choice experimental results relate to empirical findings from the wider resettlement and migration literature. One of the main problems of involuntary resettlements in the last 20 years is related to the over-reliance on compensation alone to restore people's livelihoods, ignoring the social and cultural consequences of displacement (Maldonado, 2008; Cernea and Mathur, 2007). The cultural and emotional attachment to a place is often one of the most important reasons to stay even if people's livelihoods are threatened by natural hazards (Lübken, 2012; Berg, 1999).

According to our study, the resettlement location would be the most important attribute for a future resettlement to be successful. This location preference is linked to the Bududa people's attachment to place. Both economic as well as anthropologic factors explain why they prefer to be resettled within the culturally similar Bugisu region. Soil fertility is an important economic factor for agriculture in the region (Kato and Mutonyi, 2013; Jenkins et al., 2011; Claessens et al., 2007). These soils serve as protection against food insecurity and ensure that people are

a robustness test and indication that respondents understood the experiment. Consequently we can argue that respondents took into account their current situation when answering the choice cards and that their resulting choice behavior is a good proxy for their underlying resettlement preferences. 
able to grow cash crops such as coffee in order to generate an income. The familiarity with the climate and the resulting agricultural practices that have been handed down by generations creates a strong land attachment. Bududa people have a strong cultural attachment to their place, as this place is linked to their language, the cultural acceptance of polygamy and the cultural tradition of male circumcision. These cultural habits are been frowned upon by other population groups in Uganda and people therefore fear to lose their license to practice their cultural values once they are resettled outside the Bugisu region. Bududa people often put historical attachment to their ancestral land forward as the main reason to keep on living on the steep slopes of the Mt Elgon volcano. These ancestral values pertain to former family members being buried on their family land as well as ancestral sayings such as "If you resettle, never go down, always go up." The importance of this driver is confirmed by a quote in the Ugandan Daily Monitor. After a landslide displaced around 3000 people in Bushiyi subcounty in August 2013, the newspaper quoted: "Some hesitated, preferring they would rather die on their fertile ancestral land to which they profess a sturdy bond".

Beside the fact that compensation alone will not work for the high risk group, our study shows that legacy issues matter when it comes to the relationship and trust between the government and affected communities (Correa et al., 2011). People in Bududa were asked whether they considered the risk related to a resettlement to be higher or lower than the risk of a landslide. $61 \%$ of respondents indicated that they perceived a resettlement to embody a higher risk than to stay living in the landslide-prone area. In several focus group discussions it became clear that people rationally weighted the pros and cons of a resettlement against the likelihood of a landslide occurrence. The fact that $61 \%$ of respondents considered it more likely that their livelihoods would be negatively affected by a resettlement than by a landslide originates from the negative perception of the first landslide induced resettlement by the Ugandan government 
in 2010. This resettlement took place after a landslide killed more than 350 people in the village Nametsi.

More than 600 households (4031 people), were resettled far $(400 \mathrm{~km})$ from their native places to Kiryandongo in Western Uganda, a culturally and geographically different region which was previously used as a refugee destination. The government pledged to provide housing and land, and to assist to rebuild their livelihoods. An on-site analysis of this previous resettlement by the authors with the Impoverishment Risks and Reconstruction model of Cernea (1997) showed that some essential resettlement risks where not adequately tackled and there were significant performance problems in implementing the pledges (also see Jenkins et al., 2013 for more details). Because of this, some internally displaced people returned to Bududa and spread the negative experiences they encountered during the resettlement. This consequently affected people's perception throughout the Bududa area. Linking back, our experimental findings highlight why this previous resettlement was not a success. Respondent's strongest preferences were not always taken into account by the government next to several implementation problems. Bududa people expressed a large willingness (92\%) to be involved and consulted if the government plans to use resettlement as a risk reduction strategy in the future.

\section{Conclusion and policy recommendations}

In this study, we use a discrete choice experiment to examine whether a resettlement is a feasible strategy to mitigate landslide risks on Mount Elgon, and if so under which conditions and compensatory schemes. Besides we investigate whether the willingness to resettle depends on the probability of a landslide occurring. We model heterogeneity in these preferences using a random parameters logit model and a split sample approach. 
We find considerable heterogeneity in the willingness to resettle, with people living in the most landslide-prone areas most willing to resettle. Significantly less compensation is asked by people living on the steepest slopes or in a village that has been hit by landslides in the recent past. The willingness to resettle significantly increases with monetary compensation and the acreage of land that resettled households would have access to after resettlement. This creates scope for smaller but targeted resettlement programs in which only people in the most landslideprone zones are subject to resettlement. Resettlement is likely to be most effective if resources are used to decently compensate a smaller number of the most vulnerable households - rather than to focus on a wider resettlement zone and lower compensation.

The households living in the most landslide-prone zones and faced with the highest landslide risk are poorer and younger households. As arable land is becoming increasingly scarce, newly established households are pushed to frontier areas in search for land and the poorest households are pushed to steeper, unstable slopes because they are bid out in the land market. Given that these poorer and younger households are more willing to resettle, also against a lower compensation, entails an opportunity as well as a threat. The fact that households in high-risk zones can be resettled at the smallest compensation increases the financial feasibility of resettlement. Also the resettlement of younger families, who are likely to increase in size, could provide a more long-term and structural solution to curb future population pressure on unstable slopes. The threat is that cheap resettlement, with too low compensation and lack of guidance in destination areas, further impoverishes and marginalizes the most vulnerable households. While resettlement may reduce landslide risk, it poses increased social and economic risk in the destination area (Owen and Kemp, 2014; Wilmsen et al., 2011; Stal and Warner, 2009; Schmidt-Soltau and Brockington, 2007; Cernea and SchmidtSoltau, 2006). We stress the importance of government paying equal attention to eliminating 
any social vulnerability in destination areas and provide policies for alternative livelihoods (Bui et al., 2013).

We find that the destination location of resettlement strongly influences the willingness to resettle. Although the willingness to resettle in our general model is significantly positive, the respondents have a high preference for resettlement within the Bududa district or at least within the wider, culturally similar, Bugisu region. Resettlement within the same district or region might also be preferable from a socio-cultural point of view and limit the likelihood of social disruption and marginalization of resettled households. Yet resettlement, especially large resettlement programs involving many households, within the district or region is not straightforward because of high population pressure and increasing land shortage in the whole region (Claessen et al., 2007; Knapen et al. 2006). Finding a suitable destination area within the region is difficult, which limits the possibilities for resettlement. This again calls for the careful resettlement of targeted groups of people from the most risky areas. Although not directly resulting from our study, we need to note that such resettlement is only meaningful if it is followed by a delineation of the high-risk zones people are resettled from and prevention of new encroachment in these areas. We invite future researchers to accurately identify the highrisk zones and suitable destination areas taking into account our ex-ante recommendations.

Through analysis of the preferences of the population at risk, we actively engage the communities to participate in the resettlement process and find ex-ante evidence that a combination of compensation and a people-centered, development approach will give the best results. The choice experiment and accompanying survey clearly show that government should include the cultural and social dimensions of the Bududa people, next to monetary compensation. On top of that, due to legacy issues, the government will need to improve its relationship with the affected communities to rebuild trust and reverse the negative perception 
of the previous resettlement if they want to use preventive resettlement as a successful risk reduction strategy in the future.

Our results and the derived implications show that ex ante choice experiments have merits in understanding resettlement preferences and the heterogeneity in these preferences across households, and in the design of effective resettlement policies. We can limit ex-post resettlement risks using the choice experiment as an ex-ante impact assessment tool for future risk reduction strategies. Representing alternative livelihoods by six attributes and twelve choice cards in a choice experiment is of course a simplification of reality. We acknowledge that our choice experiment does not take into account the complexity of resettlement and the links between different economic, anthropologic, and environmental factors that influence households' preferences and decisions. It might have been difficult for respondents in our choice experiment to deliberate the given alternatives and make a hypothetical choice. Several authors have argued that thinking about uncertainty, probability and risk is not straightforward (Trope and Liberman, 2003; Kahneman and Tversky, 1984). Despite these limitations, we believe that choice experimental research can result in complementary insights in the debate about environmental risks and its policy solutions. Particularly the ex-ante nature of this type of research has a merit in assessing policies and strategies before they are actually implemented. It is a relatively easy-to-implement and low-cost method to assess ex ante community support for resettlement - and potentially also other environmental-risk reduction - strategies. 


\section{Acknowledgements}

This research could never be done without the generous financial support of the VLIR-UOS which supports partnerships between universities and university colleges, in Flanders and in the South, looking for innovative responses to global and local challenges. This paper is in light of the VLIR-UOS South Initiative Project: "An Integrated Assessment of Landslides at Mount Elgon, Uganda: Hazards, Consequences and Opportunities”. The authors would like to thank the cooperation of the local communities in the Mount Elgon region in participating with the experiment. Many thanks go to the different participants of the stakeholder workshop in Mbale to shape our choice experiment and to the village heads that allowed us to conduct experiments on their grounds. Special attention needs to be given to our survey and local professional team: Wankangala Sulai, Sam, Ivan, Kevin Teopista Akoyi and Alice Nakiyemba. We thank participants at the CSAE 2015 and ICAE 2015 conferences for their valuable comments. 


\section{References}

Artur, L., \& Hilhorst, D. (2014). Floods, resettlement and land access and use in the lower Zambezi, Mozambique. Land Use Policy, 36, 361-368.

BDPU, 2012. Bududa district statistical abstract. Bududa.

Baker, J., Shaw, W. D., Bell, D., Brody, S., Riddel, M., Woodward, R. T., \& Neilson, W. (2009). Explaining subjective risks of hurricanes and the role of risks in intended moving and location choice models. Natural Hazards Review, 10(3), 102-112.

Ben-Akiva, M. E., \& Lerman, S. R. (1985). Discrete choice analysis: theory and application to travel demand (Vol. 9). MIT press.

Berg, T. M. V. (1999). “We Are Not Compensating Rocks": Resettlement and Traditional Religious Systems. World Development, 27(2), 271-283.

Black, R., Adger, W. N., Arnell, N. W., Dercon, S., Geddes, A., \& Thomas, D. (2011). The effect of environmental change on human migration. Global Environmental Change, 21, S3-S11.

Brand, L. A. (2001). Displacement for development? The impact of changing state-society relations. World Development, 29(6), 961-976.

Broothaerts, N., Kissi, E., Poesen, J., Van Rompaey, A., Getahun, K., Van Ranst, E., \& Diels, J. (2012). Spatial patterns, causes and consequences of landslides in the Gilgel Gibe catchment, SW Ethiopia. Catena, 97, 127-136.

Bui, T. M. H., Schreinemachers, P., \& Berger, T. (2013). Hydropower development in Vietnam: Involuntary resettlement and factors enabling rehabilitation. Land Use Policy, 31, 536-544.

Carson, R. T., \& Louviere, J. J. (2011). A common nomenclature for stated preference elicitation approaches. Environmental and Resource Economics, 49(4), 539-559.

Cernea, M. (1997). The risks and reconstruction model for resettling displaced populations. World development, 25(10), 1569-1587.

Cernea, M. M., \& Schmidt-Soltau, K. (2006). Poverty risks and national parks: Policy issues in conservation and resettlement. World development, 34(10), 1808-1830.

Cernea, M. M., \& Mathur, H. M. (2007). Can Compensation Prevent Impoverishment?: Reforming Resettlement Through Investments. Oxford University Press p19-98. 
Christie, M., Warren, J., Hanley, N., Murphy, K., \& Wright, R. E. (2004). Developing measures for valuing changes in biodiversity: Final Report.

Claessens, L., Knapen, A., Kitutu, M. G., Poesen, J., \& Deckers, J. A. (2007). Modelling landslide hazard, soil redistribution and sediment yield of landslides on the Ugandan footslopes of Mount Elgon. Geomorphology, 90(1), 23-35.

Claudianos, P. (2014). Out of Harm's Way; Preventive Resettlement of at Risk Informal Settlers in Highly Disaster Prone Areas. Procedia Economics and Finance, 18, 312-319.

Correa, Elena; Ramirez, Fernando; Sanahuja, Haris. (2011). Populations at risk of disaster : a resettlement guide. Washington, DC: World Bank.

Crozier, M. J., \& Glade, T. (2006). Landslide hazard and risk: issues, concepts and approach. Landslide hazard and risk. Wiley, West Sussex, 1-40.

Cummings, R. G., \& Taylor, L. O. (1999). Unbiased value estimates for environmental goods: a cheap talk design for the contingent valuation method. American Economic Review, 649-665.

Dai, F. C., Lee, C. F., \& Ngai, Y. Y. (2002). Landslide risk assessment and management: an overview. Engineering geology, 64(1), 65-87.

Dercon, S. (2006). Vulnerability: a micro perspective. Securing Development in an Unstable World, $117-146$.

Diduck, A. P., Pratap, D., Sinclair, A. J., \& Deane, S. (2013). Perceptions of impacts, public participation, and learning in the planning, assessment and mitigation of two hydroelectric projects in Uttarakhand, India. Land Use Policy, 33, 170-182

FAO. 2000. The elimination of food insecurity in the Horn of Africa - A strategy for concerted government and UN agency action. http://www.fao.org/crisis/284220103e81e5cb9759354ca34f61a3ede2bd.pdf

Glade, T., Crozier, M.J., 2004. The nature of landslide hazard impact. In: Glade, T., Anderson, M., Crozier, M. (Eds.), Landslide Hazard and Risk, pp. 43- 74.

Gorokhovich Y., Doocy S:, Walyawula F., Muwanga A, Nardi F., (2013), Landslides in Bududa, Eastern Uganda: Preliminary Assessment and Proposed Solutions, In: Landslide Science and Practice, edited by Springer Berlin Heidelberg, pp 145-149, DOI 10.1007/978-3-642-31337-0_19 
Guterres, A. (2008). Millions Uprooted-Saving Refugees and the Displaced. Foreign Aff., 87, 90.

Guzzetti F, Carrara A, Cardinali M, Reichenbach P (1999) Landslide hazard evaluation: a review of current techniques and their application in a multi-scale study, Central Italy. Geomorphol 31: $181-216$.

Holcombe, E., \& Anderson, M. (2010). Tackling landslide risk: Helping land use policy to reflect unplanned housing realities in the Eastern Caribbean. Land Use Policy, 27(3), 798-800.

Jenkins, D. H., Harris, A., Abu Tair, A., Thomas, H., Okotel, R., Kinuthia, J., \& Quince, M. (2013). Community-based resilience building: normative meets narrative in Mbale, 2010/2011. Environmental Hazards, 12(1), 47-59.

Kabra, A., \& Mahalwal, S. (2014). Impact of conservation-induced displacement on host community livelihoods: Complicating the DIDR narratives. Land Use Policy, 41, 217-224.

Kahneman, D. \& Tversky, A. (1984) Choices, values, and frames. American Psychologist,39,341-350.

Kitutu, M. G., Muwanga, A., Poesen, J., \& Deckers, J. A. (2009). Influence of soil properties on landslide occurrences in Bududa district, Eastern Uganda. African journal of agricultural research, 4(7), 611-620.

Kitutu, M. G., Muwanga, A., Poesen, J., \& Deckers, J. A. (2011). Farmer's perception on landslide occurrences in Bududa District, Eastern Uganda. African Journal of Agricultural Research, 6(1), $7-18$.

Knapen, A., Kitutu, M. G., Poesen, J., Breugelmans, W., Deckers, J., \& Muwanga, A. (2006). Landslides in a densely populated county at the footslopes of Mount Elgon (Uganda): characteristics and causal factors. Geomorphology, 73(1), 149-165.

Maldonado, J. K. (2008). Putting a price-tag on humanity: Development-forced displaced communities' fight for more than just compensation. ProQuest.

Maldonado, J. K. (2012). A New Path Forward: Researching and Reflecting on FDR Report on the International Resettlement Conference: Economics, Social Justice, and Ethics in DIM, the Hague, 4-8 October 2010. Journal of Refugee Studies, fer036.

Mugagga, F., Kakembo, V., \& Buyinza, M. (2012). Land use changes on the slopes of Mount Elgon and the implications for the occurrence of landslides. Catena, 90, 39-46. 
Lizin, S., Van Passel, S., De Schepper, E., \& Vranken, L. (2012). The future of organic photovoltaic solar cells as a direct power source for consumer electronics. Solar Energy Materials and Solar Cells, 103, 1-10.

Louviere, J. J., \& Hensher, D. A. (1982). Design and analysis of simulated choice or allocation experiments in travel choice modeling. Transportation research record, (890).

Louviere, J. J., Hensher, D. A., \& Swait, J. D. (2000). Stated choice methods: analysis and applications. Cambridge University Press.

Lübken, U. (2012). Chasing a ghost? Environmental change and migration in historical perspective. Global Environment, 9(10), 1-17.

Owen, J. R., \& Kemp, D. (2014). Mining-Induced Displacement and Resettlement: A Critical Appraisal. Journal of Cleaner Production (In Press). DOI: 10.1016/j.jclepro.2014.09.087

Oxfam. 2008. Turning up the Heat: Climate change and poverty in Uganda. Research report prepared by Magrath John. ISBN: 9781848140394

Rukundo, P. M., Iversen, P. O., Oshaug, A., Omuajuanfo, L. R., Rukooko, B., Kikafunda, J., \& Andreassen, B. A. (2014). Food as a human right during disasters in Uganda. Food Policy, 49, $312-322$.

Schmidt-Soltau, K., \& Brockington, D. (2007). Protected areas and resettlement: What scope for voluntary relocation? World Development, 35(12), 2182-2202.

Shiferaw, B. (2002). Poverty and natural resource management in the semi-arid tropics: Revisiting challenges and conceptual issues. ICRISAT.

Stal., M., Warner., K. 2009. Research Brief based on the Outcomes of the 2nd Expert Workshop on Climate Change, Environment, and Migration 23 - 24 July 2009, Munich, Germany

Swait, J., \& Louviere, J. (1993). The role of the scale parameter in the estimation and comparison of multinomial logit models. Journal of Marketing Research, 305-314.

Trope, Y., \& Liberman, N. (2003). Temporal construal. Psychological review, 110(3), 403.

United Nations Development Programme (UNDP). 2004. Gender and Energy for Sustainable Development: A Toolkit and Resource Guide. New York: UN 
Van Den Eeckhaut, M., Reichenbach, P., Guzzetti, F., Rossi, M., \& Poesen, J. (2009). Combined landslide inventory and susceptibility assessment based on different mapping units: an example from the Flemish Ardennes, Belgium. Nat. Hazards Earth Syst. Sci, 9, 507-521.

Vu, Q. M., Le, Q. B., Frossard, E., \& Vlek, P. L. (2014). Socio-economic and biophysical determinants of land degradation in Vietnam: An integrated causal analysis at the national level. Land Use Policy, 36, 605-617.

WB/UN. (2010). Natural hazards, unnatural disasters: the economics of effective prevention.

Webber, M., \& McDonald, B. (2004). Involuntary resettlement, production and income: Evidence from Xiaolangdi, PRC. World Development, 32(4), 673-690.

Wilmsen, B., Webber, M., \& Yuefang, D. (2011). Development for whom? Rural to urban resettlement at the Three Gorges Dam, China. Asian Studies Review, 35(1), 21-42.

Wilmsen, B., Webber, M., \& Duan, Y. (2011). Involuntary rural resettlement: resources, strategies, and outcomes at the three Gorges Dam, China. The Journal of Environment \& Development. 